\title{
PEMBERDAYAAN MASYARAKAT SUNGAI LULUT DALAM PENGELOLAAN SAMPAH BERBASIS 3R SEBAGAI UPAYA MITIGASI BANJIR
}

\author{
Farida Heriyani ${ }^{1}$, Lia Yulia Budiarti ${ }^{2}$, Widya Nursantari ${ }^{1}$ \\ ${ }^{1}$ Departemen Ilmu Kesehatan Masyarakat, Fakultas Kedokteran Universitas Lambung Mangkurat \\ ${ }^{2}$ Departemen Mikrobiologi dan Parasitologi, Fakultas Kedokteran Universitas Lambung Mangkurat \\ Email penulis : fheriyani@ulm.ac.id, lybudiarti@ulm.ac.id, widya.nursantari@ulm.ac.id
}

\begin{abstract}
Abstrak
Kelurahan Sungai Lulut merupakan salah satu wilayah di Kota Banjarmasin yang terdampak banjir cukup parah dan dalam waktu lama. Ketinggian air mencapai dada orang dewasa dan menggenangi hampir seluruh wilayah Kelurahan Sungai Lulut. Kondisi wilayahnya yang memiliki banyak aliran sungai dan sebagian besar penduduk bermukim di bantaran sungai. Kelurahan ini memiliki jumlah penduduk sebanyak 15.925 jiwa dengan kepadatan penduduk mencapai 5.398 jiwa $/ \mathrm{km}^{2}$. Di daerah ini hanya terdapat 2 TPS yang tentu saja sangat kurang untuk menampung sampah dari hasil aktivitas penduduknya, selain itu letak TPS yang jauh dari pemukiman menyebabkan banyak warga yang membuang sampah sembarangan salah satunya ke aliran sungai sehingga mengakibatkan sumbatan aliran sungai yang sangat berkontribusi terhadap banjir di wilayah tersebut. Kegiatan ini bertujuan untuk meningkatkan pengetahuan dan keterampilan masyarakat dalam pengelolaan sampah yang benar. Kegiatan ini berupa pemberdayaan masyarakat dengan memberikan edukasi dan pelatihan kepada masyarakat dalam pengelolaan sampah berbasis 3R (Reduse, Reuse, dan Recycle) sebagai upaya pelestarian lingkungan dan mitigasi banjir. Hasil kegiatan didapatkan peningkatan pengetahuan dan keterampilan peserta tentang pengelolaan sampah yang benar dan menjadi tergerak untuk melakukan daur ulang sampah sebagai salah satu cara untuk mengelola sampah dalam upaya mitigasi banjir.
\end{abstract}

Kata kunci : pemberdayaan masyarakat, pengelolaan sampah, mitigasi banjir

\section{PENDAHULUAN}

Banjir yang melanda Provinsi Kalimantan Selatan (Kalsel) pada awal tahun 2021 meluas hingga Kota Banjarmasin. Badan SAR Nasional (Basarnas) menyebut setidaknya 9.600 jiwa terdampak banjir di wilayah Kota Banjarmasin. Wali Kota Banjarmasin, Ibnu Sina menetapkan status tanggap darurat banjir sejak 15 Januari lalu, menyusul banyaknya rumah warga yang terendam dan terparah terjadi pada Jumat, di mana ketinggian air terus meningkat di sejumlah daerah. Sekitar 600 rumah yang tersebar di 5 kecamatan terendam banjir di Kota Banjarmasin. (Makdori, 2021; Haswar, 2021)

Sebanyak 25 kelurahan yang terdampak banjir cukup dalam dan yang terbanyak di 
Banjarmasin Timur yakni sembilan kelurahan. Di Banjarmasin Timur, jumlah warga terdampak banjir sekitar 45 ribu jiwa atau sekitar 15 ribu kepala keluarga (KK). Bahkan sebanyak $1.585 \mathrm{KK}$ atau 3.701 jiwa harus mengungsi ke tempat yang lebih aman. Kelurahan Sungai Lulut merupakan daerah yang terdampak banjir paling besar dan lama (Yulika, 2021).

Penyebab banjir di Kalsel hingga saat ini masih menjadi perdebatan. Bahkan, sejumlah penggiat lingkungan mengungkapkan bahwa banjir di Kalsel terjadi karena faktor penyerta seperti deforestasi hutan untuk lahan sawit dan pertambangan. Analisis dari Lembaga Penerbangan dan Antariksa Nasional (LAPAN) bahwa Kalimantan telah kehilangan hutan sampai 300.000 hektar. Bareskrim Polri juga mengeluarkan pendapat bahwa penyebab banjir karena ada pasang di laut (CNN Indonesia, 2021).

Untuk Kota Banjarmasin, selain karena hal tersebut, kondisi kota Banjarmasin yang memiliki banyak aliran sungai dan penduduk yang bermukim di bantaran sungai dengan berbagai aktivitasnya serta buruknya perilaku pembuangan sampah oleh masyarakat mengakibatkan sumbatan aliran sungai sehingga air sungai tergenang di jalan dan pemukiman sehingga banjir menjadi lambat surut.

Kelurahan Sungai Lulut adalah salah satu wilayah kelurahan di Kecamatan Banjarmasin Timur yang mengalami banjir yang parah dan lama. Ketinggian air mencapai dada orang dewasa dan menggenangi hampir seluruh wilayah Kelurahan Sungai Lulut, sehingga sebagian besar warganya harus mengungsi ke berbagai tempat pengungsian (CNN Indonesia, 2021).

Wilayah Kelurahan Sungai Lulut merupakan wilayah dataran rendah yang berada pada ketinggian 65 kaki dari permukaan air laut, dengan luas wilayah $2,95 \mathrm{~km}^{2}$. Terdapat aliran sungai di sepanjang wilayahnya dengan banyak cabangcabang sungai kecil. Dengan jumlah penduduk sebanyak 15.925 jiwa terbagi dalam 28 RT, menjadikan wilayah ini sebagai daaerah yang sangat padat dengan kepadatan penduduk sebesar 5.398 jiwa $/ \mathrm{km}^{2}$. Ratio penduduk usia produktif sebesar 70,,9\% namun status ekonomi penduduknya masih tergolong menengah ke bawah.

Di daerah ini dengan jumlah penduduk mencapai 15.925 jiwa hanya ada 2 TPS sebagai tempat penampungan sementara sampah-sampah yang dihasilkan oleh penduduknya. Mengakibatkan kondisi TPS yang tidak mampu menampung sampah-sampah sehingga kondisi TPS menjadi berantakan, banyak sampah yang berhamburan keluar dari TPS. Kondisi ini dapat mencemari lingkungan sekitar. Selain itu, letak TPS yang jauh dari pemukiman, sehingga banyak warga yang membuang sampah sembarangan salah satunya ke aliran sungai sehingga mengakibatkan sumbatan aliran sungai, banyak anak-anak sungai yang tersumbat alirannyaoleh tumpukan sampah. Kondisi ini sangat berkontribusi terhadap banjir yang terjadi di wilayah tersebut (Puskesmas Terminal, 2020).

Kondisi pascabanjir menunjukkan banyaknya tumpukan sampah berserakan yang terbawa oleh aliran air banjir. Di sekitar TPS pun terlihat kondisinya menjadi sangat tidak layak karena sampah melebihi kapasitas. Hal ini tentu saja sangat tidak sehat bagi masyarakat karena dapat mencemari lingkungan sekitar di daerah tersebut.

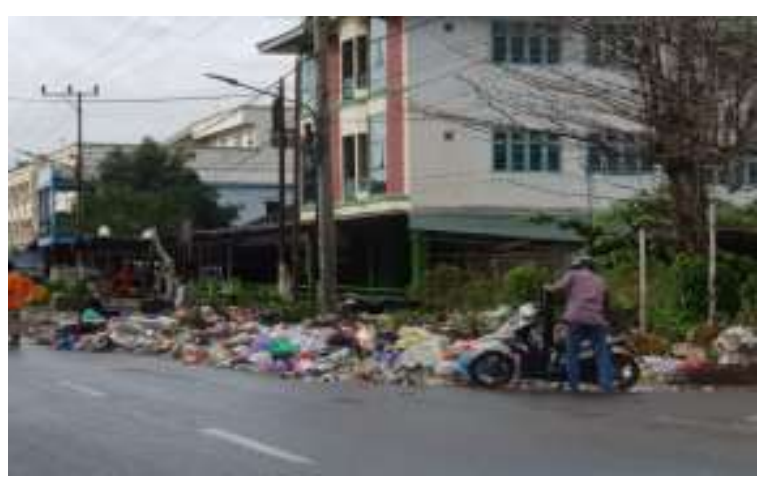




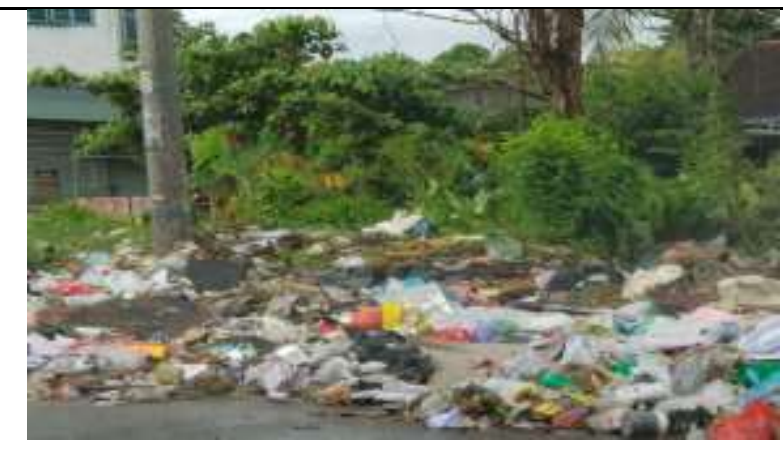

Gambar 1. Kondisi TPS dan sekitarnya pascabanjir di Kelurahan Sungai Lulut Banjarmasin.

Angka kejadian penyakit yang berkaitan dengan sampah dan banjir seperti diare, ISPA, dermatitis dan candidiasis pada kaki juga meningkat. Banyak pengungsi di penampungan yang mengalami diare, muntah-muntah dan kaki yang belancat (candidiasis cutis) (Puskesmas Terminal 2020).

Untuk mengatasi masalah ini, perlu adanya sosialisasi pengelolaan sampah yang baik dan benar agar dapat mengurangi jumlah sampah yang dihasilkan masyarakat dan sampah yang dibuang ke TPS sesuai kapasitas sehingga tidak mencemari lingkungan (Riswan dkk, 2011). Pembuangan sampah yang tidak sehat dapat menyebabkan kondisi lingkungan baik tanah, air dan udara di sekitarnya menjadi tercemar oleh sampah dan mikroorganisme dari sampah yang ada. Hal ini sangat mungkin menyebabkan masalah kesehatan bagi penduduk di wilayah tersebut. Apabila sampah dibuang ke aliran sungai yang ada di daerah ini, maka terjadi penyumbatan aliran sungai sehingga pada saat air pasang dapat menyebabkan banjir di daerah sekitarnya yang cukup lama karena air lambat surut dan berdampak terhadap pencemaran air sungai.

Berdasarkan laporan Badan Lingkungan Hidup Kota Banjarmasin tahun 2014, menyebutkan bahwa sungai dan anak sungai Martapura sudah tercemar secara biologi dengan Coliform tinja penyebab infeksi diare yaitu sekitar 233/100ml sampel air sungai (Sofarini dkk, 2012). Persyaratan bakteriologis terhadap air bersih sesuai syarat kesehatan adalah dengan tidak adanya bakteri Escherichia coli (E.coli) (Swastika D,
2017). Menurut Surat Keputusan Menteri Kesehatan NO.416/Menkes/SK/IX/1990 tentang syarat - syarat dan pengawasan kualitas air, yaitu kandungan E.coli dan total koliform sebesar 0 JPT/100 ml sampel (Marhamah S, 2013).

Selain itu, keberadaan sungai-sungai kecil yang ada di Kota Banjarmasin seperti Sungai Lulut, Sungai Jafri Zam-zam, Sungai Basirih, Sungai Kuin dan Sungai Alalak telah terdeteksi memiliki kandungan biochemical oxigen demand (BOD) berkisar antara 2,2 sampai 3,18 mg/liter, yang berada di atas ambang batas (Sofarini dkk, 2012).

Kuantitas air sungai di Banjarmasin saat ini debit airnya sudah berkurang. Hal itu, mengakibatkan air pasang yang berasal dari laut lebih dominan mendesak masuk ke sungai sehingga air sungai terasa asin. Selain asin, air sungai di perkotaan juga kotor karena sungai di Banjarmasin hingga kini masih menjadi tempat pembuangan sampah nomor satu bagi warga kota. Kondisi air sungai di Banjarmasin yang tercemar tentu sudah tidak layak konsumsi dan juga kadar garam (salinitas) sudah mencapai 20 kali ambang normal atau 5.000 miligram per liter (Pusat Litbang SDA, 2004; BLHD, 2012).

Hasil penelitian Heriyani, dkk (2018) di darerah bantaran Sungai Lulut Banjarmasin menunjukkan jenis bakteri yang diisolasi dari 50 sampel swab tangan setelah mencuci tangan dengan sabun cuci tangan adalah 34 isolat Staphylococcus aureus (68\%), 14 isolat Escherichia coli (48\%), dan 2 isolat Staphylococcus epidermidis (4\%). Jenis isolat bakteri yang teridentifikasi dari 50 sampel tinja adalah 41 isolat Escherichia coli (82\%) dan 9 isolat Salmonella typhi (12\%). Hasil pemeriksaan MPN coliform dari 30 sampel air perpipaan didapat rerata coliform tinja sebesar 2.04.0/100ml sampel air, jenis bakteri coliform yang teridentifikasi yaitu Escherichia coli.

Letak TPS yang berada di lokasi bantaran sungai dengan kondisi yang tidak sesuai dengan persyaratan sebagai TPS yang sehat, kedua TPS ini ditutup oleh Dinas Kebersihan Kota Banjarmasin. Hal ini mengakibatkan permasalahan baru yaitu bagi masyarakat setempat karena tidak ada lagi tempat untuk penampungan sementara sampah. Ini menjadi tantangan baru yang perlu dicarikan 
solusinya agar sampah yang dihasilkan setiap hari tidak menumpuk dan mengakibatkan masalah bagi lingkungan dan masyarakat setempat.

Kepadatan penduduk di Kelurahan Sungai Lulut yang sangat tinggi tentu saja menghasilkan jumlah sampah rumah tangga yang banyak dan bervariasi sehingga jika tidak dikelola dengan baik dan benar akan menimbulkan masalah bagi lingkungan dan kesehatan masyarakat setempat. Sumaryadi (2005) mengemukakan bahwa pembangunan partisipatif merupakan pendekatan pembangunan yang sesuai dengan hakikat otonomi daerah yang meletakkan landasan pembangunan yang tumbuh berkembang dari masyarakat, diselenggarakan secara sadar dan mandiri oleh masyarakat dan hasilnya dinikmati oleh seluruh masyarakat. Melalui pembangunan partisipatif tersebut diharapkan semua elemen masyarakat dapat secara bersama-sama berpartisipasi dengan cara mencurahkan pemikiran dan sumber daya yang dimiliki guna memenuhi kebutuhannya sendiri.

Upaya mengurangi risiko bencana (mitigasi), termasuk bencana banjir, dapat dilakukan oleh pemerintah, masyarakat, bahkan individu sendiri. Menurut Undang-undang Nomor 24 tahun 2007, mitigasi adalah serangkaian upaya mengurangi risiko bencana melalui pembangunan fisik maupun penyadaran dan peningkatan kemampuan menghadapi ancaman bencana, tentu saja dilakukan untuk mengurangi risiko bencana bagi masyarakat yang berada pada kawasan rawan bencana. Kegiatan mitigasi tersebut dapat dilakukan melalui : pelaksanaan penataan ruang, pengaturan pembangunan, pembangunan infrastruktur, tata bangunan, penyelenggaraan pendidikan, penyuluhan dan pelatihan baik secara konvensional maupun modern (kompas.com).

Pada permasalahan di atas, salah satu upaya mitigasi yang dapat dilakukan yaitu adanya pengelolaan sampah berbasis Reduce-ReuseRecycle (TPS 3R) yang merupakan pola pendekatan pengelolaan persampahan pada skala komunal atau kawasan yang melibatkan peran aktif pemerintah dan masyarakat. Termasuk untuk masyarakat berpenghasilan rendah dan/atau yang tinggal di permukiman yang padat atau kumuh.
Penanganan sampah dengan pendekatan infrastruktur TPS 3R lebih menekankan kepada cara pengurangan, pemanfaatan dan pengolahan sejak dari sumbernya (Hariyadi, dkk. 2020).

Permasalahan mitra yang diangkat untuk ditindaklanjuti melalui kegiatan pengabdian masyarakat ini yaitu berdasarkan lokasi, kondisi lingkungan, masyarakat dan perilaku masyarakat dan berdasarkan data-data laporan kasus penyakit pascabanjir. Berdasarkan lokasi, kondisi masyarakat, dan perilaku: (1) lokasi tempat tinggal mitra yang berada di bantaran sungai dan terjadi banjir yang luas serta tinggi dalam waktu yang lama, (2) kondisi pascabanjir dimana banyak sekali sampah yang mengotori lingkungan penduduk maupun di TPS setempat, (3) jumlah penduduk dengan kepadatan penduduk tergolong sangat padat sehingga produksi sampah yang sangat tinggi berkontribusi dalam terjadinya bencana banjir, (4) tidak ada lagi TPS karena sudah ditutup oleh Dinas Kesehatan, (5) tingginya angka kejadian penyakit yang berhubungan dengan pencemaran sampah dan penggunaan air sungai yang sudah tercemar (ISPA, dermatitis, dan diare). Selanjutnya berdasarkan hasil-hasil penelitian sebelumnya: (1) hasil penelitian mengenai coliform pada air sungai dan air perpipaan di bantaran Sungai Lulut Banjarmasin yang sangat tinggi, (2) hasil penelitian yang mendapatkan populasi bakteri patogen pada tangan anak-anak yang bertempat tinggal di bantaran Sungai Lulut Banjarmasin.

Solusi yang ditawarkan untuk menyelesaikan permasalahan yang terjadi di Kelurahan Sungai Lulut Banjarmasin melalui strategi pemberdayaan masyarakat, yaitu berupa melakukan sosialisasi dan edukasi kepada masyarakat dalam pengelolaan sampah berbasis $3 \mathrm{R}$ (Reduse, Reuse, dan Recycle) sebagai upaya pelestarian lingkungan dan mitigasi banjir serta memberikan contoh dan pelatihan tentang cara Recycle, yaitu mendaur ulang atau menggunakan kembali sampah yang masih dapat digunakan untuk fungsi yang sama ataupun lainnya dalam rangka mengurangi jumlah sampah sebagai upaya mitigasi banjir sekaligus meningkatkan ekonomi masyarakat setempat. 


\section{METODE}

Untuk kegiatan sosialisasi dan edukasi digunakan pendekatan kelompok dengan metode ceramah dan diskusi serta tanya jawab yang disampaikan secara sederhana, informatif dan menarik mengenai materi: 1)Kontribusi sampah pada terjadinya banjir, 2)Jenis-jenis sampah, 3)Pentingnya pengelolaan sampah dengan benar berbasis 3R (Reduse, Reuse, dan Recycle) dalam mitigasi banjir, 4)Cara pengelolaan sampah dengan benar berbasis 3R (Reduse, Reuse, dan Recycle.

Pelaksanaan dilakukan secara langsung dengan menerapkan protokol kesehatan untuk pencegahan penularan covid-19, yaitu kegiatan dilakukan di tempat yang cukup luas dan hanya diisi dengan maksimal 50\% kapasitas tempat tersebut, semua peserta tetap menjaga jarak, telah menggunakan masker dengan benar, sebelum masuk membersihkan tangan dengan sabun dan air mengalir atau hand sanitizer, melakukan pengecekan suhu tubuh. Panitia akan menyediakan masker dan desinfektan cadangan.

Kemudian dilanjutkan dengan memberikan peragaan atau contoh cara mendaur ulang sampah agar bisa kembali digunakan untuk fungsi yang sama ataupun fungsi baru dari sampah tersebut. Kegiatan ini juga disertai dengan pemutaran video pemanfaatan kembali sampah menjadi barang yang berguna. Sebelum dan sesudah pemberian materi dilakukan pretest dan posttest untuk mengetahui pemahaman peserta mengenai materi yang telah disampaikan sebagai evaluasi jangka pendek untuk mengetahui dampak dari hasil pelatihan ini. Evaluasi jangka panjang dilihat dari produksi dan jumlah sampah serta kegiatan daur ulang sampah di masyarakat setempat. Semua proses kegiatan akan didokumentasikan dalam bentuk video dan foto.

\section{HASIL DAN PEMBAHASAN}

Telah dilaksanakan kegiatan pengabdian kepada masyarakat berupa pemberdayaan masyarakat Sungai Lulut dalam pengelolaan sampah berbasis 3R dalam rangka mitigasi banjir. Kegiatan dilakukan melalui strategi pemberdayaan masyarakat, yaitu berupa :1) Melakukan sosialisasi dan edukasi kepada masyarakat dalam pengelolaan sampah berbasis 3R (Reduse, Reuse, dan Recycle) sebagai upaya pelestarian lingkungan dan mitigasi banjir, dan 2)Memberikan contoh dan pelatihan tentang cara Recycle, yaitu mendaur ulang atau menggunakan kembali sampah yang masih dapat digunkan untuk fungsi yang sama ataupun lainnya dalam rangka mengurangi jumlah sampah sebagai upaya mitigasi banjir sekaligus meningkatkan ekonomi masyarakat setempat.

Mitra sasaran pada kegiatan ini adalah IbuIbu rumah tangga yang bertempat tinggal di RT 9 dan 10 Kelurahan Sungai Lulut Banjarmasin. Jumlah sasaran adalah 25 orang.

Pelaksanaan dilakukan secara langsung dengan menerapkan protokol kesehatan untuk pencegahan penularan covid-19, yaitu kegiatan dilakukan di tempat yang cukup luas dan terebuka, hanya diisi dengan maksimal 50\% kapasitas tempat tersebut, yaitu diikuti 25 orang peserta, semua peserta tetap menjaga jarak, menggunakan masker dengan benar, sebelum masuk membersihkan tangan dengan sabun dan air mengalir atau hand sanitizer, serta melakukan pengecekan suhu tubuh. Panitia juga menyediakan masker dan desinfektan cadangan.

Dalam kegiatan sosialisasi dan edukasi digunakan pendekatan kelompok dengan metode ceramah dan diskusi serta tanya jawab yang disampaikan secara sederhana, informatif dan menarik mengenai materi: 1)Kontribusi sampah pada terjadinya banjir, 2)Jenis-jenis sampah, 3)Pentingnya pengelolaan sampah dengan benar berbasis 3R (Reduse, Reuse, dan Recycle) dalam mitigasi banjir, dan 4)Cara pengelolaan sampah dengan benar berbasis 3R (Reduse, Reuse, dan Recycle) 


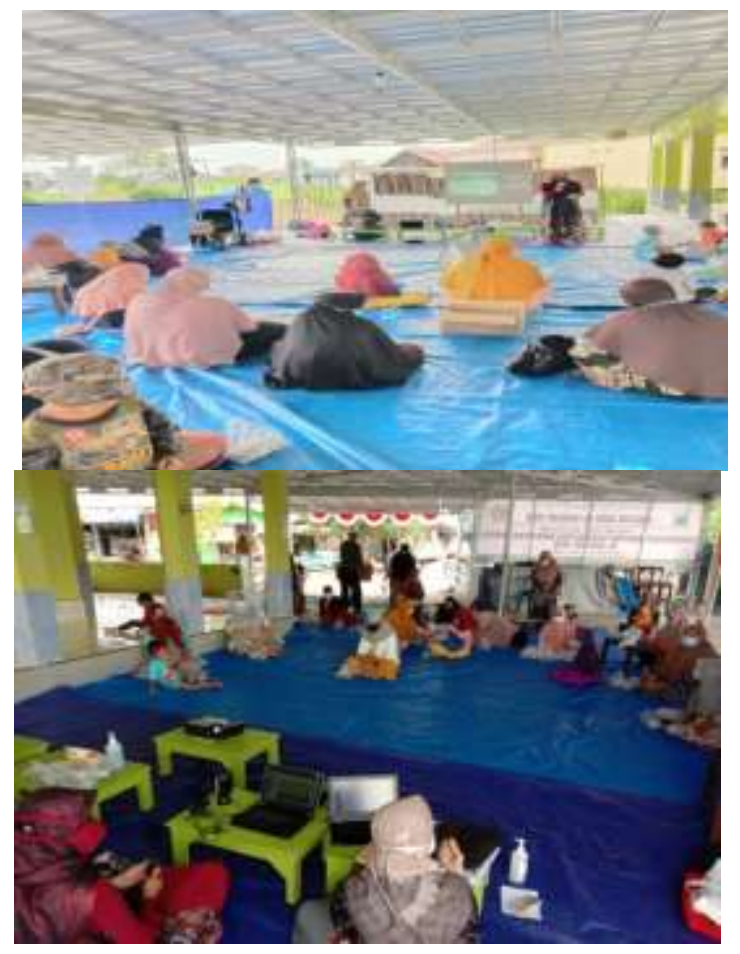

Gambar 2. Kegiatan pemberian materi kontribusi sampah terhadap banjir dan pengelolaan sampah berbasis 3R sebagai upaya mitigasi banjir di Kelurahan Sungai Lulut.

Kemudian dilanjutkan dengan memberikan peragaan atau contoh cara mendaur ulang sampah agar bisa kembali digunakan untuk fungsi yang sama ataupun fungsi baru dari sampah tersebut. Kegiatan ini juga disertai dengan pemutaran video pemanfaatan kembali sampah menjadi barang yang berguna.

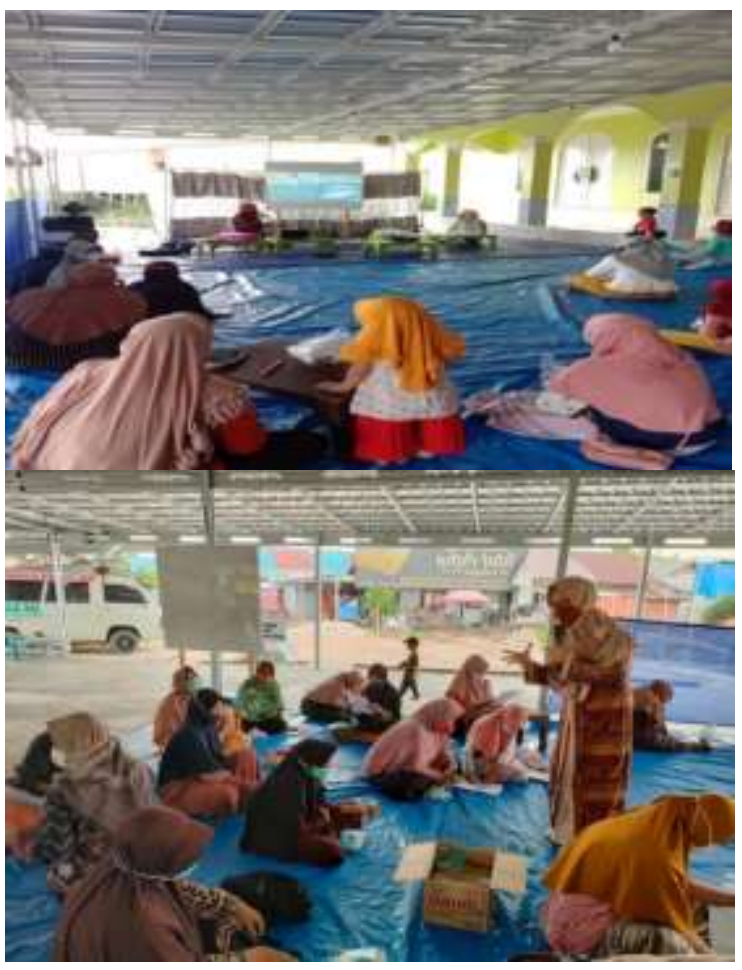

Gambar 3. Pemutaran video dan peragaan cara daur ulang sampah di Kelurahan Sungai Lulut Banjarmasin

Sebelum dan sesudah pemberian materi dilakukan pretest dan posttest untuk mengetahui pemahaman peserta mengenai materi yang telah disampaikan sebagai evaluasi jangka pendek untuk mengetahui dampak dari hasil pelatihan ini. Evaluasi jangka panjang dilihat dari produksi dan jumlah sampah serta kegiatan daur ulang sampah di masyarakat setempat. 


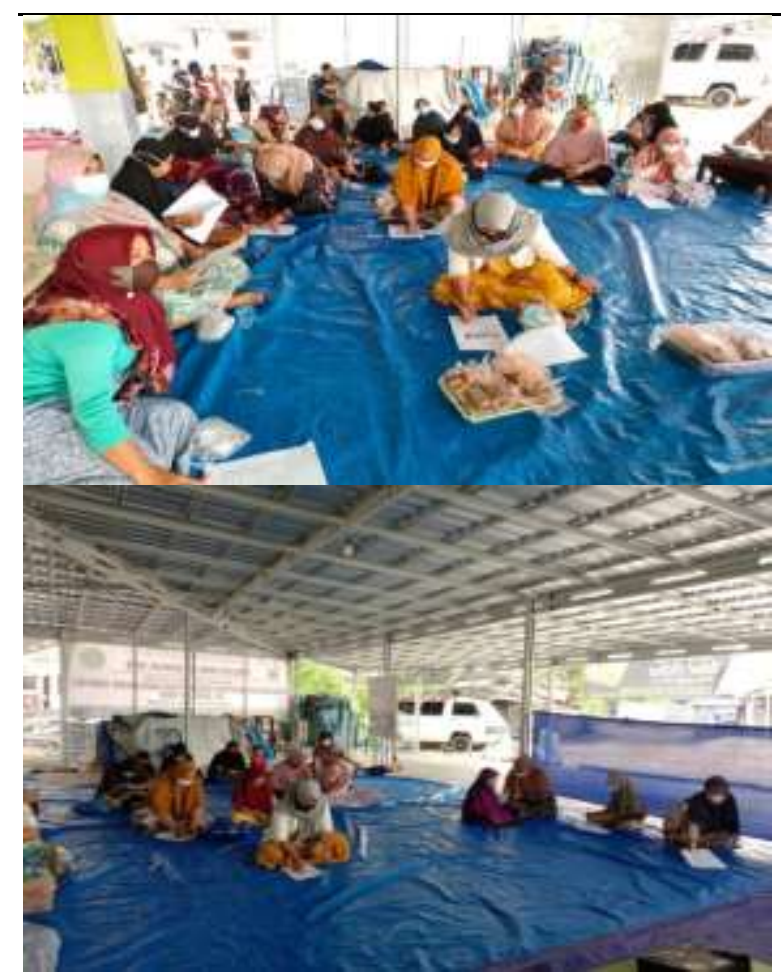

Gambar 4. Pelaksanaan pretes dan postes

Tabel 1. Hasil pretes dan postes pengetahuan peserta tentang sampah dan pengelolaan sampah berbasis $3 \mathrm{R}$ dalam rangka mitigasi banjir

\begin{tabular}{ccccc}
\hline Nilai & \multicolumn{2}{c}{ Pretes } & \multicolumn{2}{c}{ Postes } \\
\cline { 2 - 5 } & $\mathrm{n}$ & $\%$ & $\mathrm{n}$ & $\%$ \\
\hline 1 & - & - & - & - \\
2 & 2 & & - & \\
3 & - & & - & \\
4 & - & & - & \\
5 & 3 & & - & \\
6 & 6 & & 2 & \\
7 & 7 & & - & \\
8 & 6 & & 3 & \\
9 & 1 & & 5 & \\
10 & - & & 15 & \\
\hline Jumlah & 25 & 100 & 25 & 100 \\
\hline Rata- & 6,44 & & 9,24 & \\
rata & & & & \\
\hline
\end{tabular}

Berdasarkan tabel 1, diketahui bahwa pada pretes ada 5 orang dengan nilai dibawah 6 dengan rata-rata nilai 6,44 . Hal ini menunjukkan bahwa masih banyak masyarakat yang memiliki pengetahuan yang kurang tentang kontribusi sampah terhadap banjir dan bagaimana pengelolaan sampah yang benar. Hasil postes yang dilakukan setelah pemberian materi didapatkan peningkatan nilai dengan rata-rata nilai menjadi 9,24. Hal ini menunjukkan adanya peningkatan pengetahuan peserta.

Data diuji normalitas dengan uji ShapiroWilk didapatkan nilai $p$ untuk pretes sebesar 0,003 dan postes 0,000 yang menunjukkan data tidak terdistribusi normal. Dilanjutkan dengan uji Wilcoxon, didapatkan nilai $p$ sebesar 0,000 . Hal ini menunjukkan terdapat peningkatan bermakna nilai postes dibandingkan nila pretes.

Semua peserta juga mempunyai pengetahuan dan kesadaran tentang pentingnya mengelola sampah dengan baik sebagai upaya mitigasi banjir dan mereka mempunyai keterampilan dasar cara mendaur ulang sampah menjadi barang yang bermanfaat dan mempunyai nilai ekonomis. Umumnya mereka tergerak untuk melakukan pengelolaan sampah secara $3 \mathrm{R}$ guna mengurangi jumlah sampah dan mendapatkan barang daur ulang yang bisa digunakan serta sebagai salah satu upaya untuk mencegah banjir.

Pengetahuan merupakan hasil "tahu" dan hal ini terjadi setelah orang melakukan penginderaan terhadap suatu objek tertentu. Penginderaan terjadi melalui panca indra manusia, yakni indra penglihatan, pendengaran, penciuman, rasa dan raba. Sebagian besar pengetahuan diperoleh melalui mata dan telinga (Notoatmodjo, 2012).

Pengetahuan merupakan salah satu unsur yang diperlukan seseorang diantaranya : a) pengetahuan/pengertian dan pemahaman tentang apa yang dilakukannya; b) keyakinan dan kepercayaan tentang manfaat dan kebenaran dari apa yang dilakukannya; c) sarana yang diperlukan untuk melakukannya; dan d) dorongan atau motivasi untuk berbuat yang dilandasi oleh kebutuhan yang dirasakan (Notoatmodjo, 2012).

Menurut teori dari Rogers, dalam Notoatmodjo (2012), perilaku yang didasari oleh pengetahuan akan lebih baik dari pada perilaku 
yang tidak didasari oleh pengetahuan. Semakin tinggi tingkat pengetahuan seseorang tentang suatu hal maka semakin tahu dia tentang pentingnya hal tersebut termasuk tentang pengelolaan sampah di rumah tangga. Dengan semakin meningkatnya pengetahuan seseorang tentang pengelolaan sampah dan mitigasi banjir agar dapat mengurangi jumlah sampah yang dibuang lingkungan sehingga tidak mencemari lingkungan, lingkungan menjadi lebih bersih dan sehat, penduduk sekitar terhindar dari masalah atau penyakit yang dapat diakibatkannya maupun bahaya banjir di kemudian hari.

Sebagai keberlanjutan kegiatan ini akan dilakukan motitoring dan evaluasi pengelolaan sampah berbasis 3R di masyarakat. Monitoring dan evaluasi ini dilakukan bekerjasama dengan tokoh masyarakat dan ketua RT setempat. Evaluasi jangka panjang dilihat produksi sampah yang dibuang ke TPS atau lingkungan dan produtivitas daur ulang sampah serta tidak terjadinya sumbatan aliran sungai atau selokan yang bisa mencegah terjadinya banjir.

Wilayah Kelurahan Sungai Lulut merupakan wilayah dataran rendah yang berada pada ketinggian 65 kaki dari permukaan air laut, dengan luas wilayah $2,95 \mathrm{~km}^{2}$. Terdapat aliran sungai di sepanjang wilayahnya dengan banyak cabangcabang sungai kecil. Dengan jumlah penduduk sebanyak 15.925 jiwa terbagi dalam 28 RT, menjadikan wilayah ini sebagai daaerah yang sangat padat dengan kepadatan penduduk sebesar $5.398 \mathrm{jiwa} / \mathrm{km}^{2}$. Ratio penduduk usia produktif sebesar 70,,9\% namun status ekonomi penduduknya masih tergolong menengah ke bawah.

Di daerah ini dengan jumlah penduduk mencapai 15.925 jiwa hanya ada 2 TPS sebagai tempat penampungan sementara sampah-sampah yang dihasilkan oleh penduduknya. Mengakibatkan kondisi TPS yang tidak mampu menampung sampah-sampah sehingga kondisi TPS menjadi berantakan, banyak sampah yang berhamburan keluar dari TPS. Kondisi ini dapat mencemari lingkungan sekitar. Selain itu, letak TPS yang jauh dari pemukiman, sehingga banyak warga yang membuang sampah sembarangan salah satunya ke aliran sungai sehingga mengakibatkan sumbatan aliran sungai, banyak anak-anak sungai yang tersumbat alirannya oleh tumpukan sampah. Kondisi ini sangat berkontribusi terhadap banjir yang terjadi di wilayah tersebut (Puskesmas Terminal, 2020).

Kondisi pascabanjir menunjukkan banyaknya tumpukan sampah berserakan yang terbawa oleh aliran air banjir. Di sekitar TPS pun terlihat kondisinya menjadi sangat tidak layak karena sampah melebihi kapasitas. Hal ini tentu saja sangat tidak sehat bagi masyarakat karena dapat mencemari lingkungan sekitar di daerah tersebut.

Pengelolaan sampah yang baik dan benar agar dapat mengurangi jumlah sampah yang dihasilkan masyarakat dan sampah yang dibuang ke TPS sesuai kapasitas sehingga tidak mencemari lingkungan (Riswan dkk, 2011). Pembuangan sampah yang tidak sehat dapat menyebabkan kondisi lingkungan baik tanah, air dan udara di sekitarnya menjadi tercemar oleh sampah dan mikroorganisme dari sampah yang ada. Hal ini sangat mungkin menyebabkan masalah kesehatan bagi penduduk di wilayah tersebut. Apabila sampah dibuang ke aliran sungai yang ada di daerah ini, maka terjadi penyumbatan aliran sungai sehingga pada saat air pasang dapat menyebabkan banjir di daerah sekitarnya yang cukup lama karena air lambat surut dan berdampak terhadap pencemaran air sungai.

Sumaryadi (2005) mengemukakan bahwa pembangunan partisipatif merupakan pendekatan pembangunan yang sesuai dengan hakikat otonomi daerah yang meletakkan landasan pembangunan yang tumbuh berkembang dari masyarakat, diselenggarakan secara sadar dan mandiri oleh masyarakat dan hasilnya dinikmati oleh seluruh masyarakat. Melalui pembangunan partisipatif tersebut diharapkan semua elemen masyarakat dapat secara bersama-sama berpartisipasi dengan cara mencurahkan pemikiran dan sumber daya yang dimiliki guna memenuhi kebutuhannya sendiri.

Upaya mengurangi risiko bencana (mitigasi), termasuk bencana banjir, dapat dilakukan oleh pemerintah, masyarakat, bahkan individu sendiri. Menurut Undang-undang Nomor 24 tahun 2007, 
mitigasi adalah serangkaian upaya mengurangi risiko bencana melalui pembangunan fisik maupun penyadaran dan peningkatan kemampuan menghadapi ancaman bencana, tentu saja dilakukan untuk mengurangi risiko bencana bagi masyarakat yang berada pada kawasan rawan bencana. Kegiatan mitigasi tersebut dapat dilakukan melalui : pelaksanaan penataan ruang, pengaturan pembangunan, pembangunan infrastruktur, tata bangunan, penyelenggaraan pendidikan, penyuluhan dan pelatihan baik secara konvensional maupun modern (kompas.com).

Pada permasalahan di atas, salah satu upaya mitigasi yang dapat dilakukan yaitu adanya pemberyaan masyarakat dalam pengelolaan sampah berbasis Reduce-Reuse-Recycle (TPS 3R) yang merupakan pola pendekatan pengelolaan persampahan pada skala komunal atau kawasan yang melibatkan peran aktif pemerintah dan masyarakat. Termasuk untuk masyarakat berpenghasilan rendah dan/atau yang tinggal di permukiman yang padat atau kumuh. Penanganan sampah dengan pendekatan infrastruktur TPS 3R lebih menekankan kepada cara pengurangan, pemanfaatan dan pengolahan sejak dari sumbernya (Hariyadi, dkk. 2020).

Dengan memberikan pengetahuan dan keterampilan tentang pengelolaan sampah berbasis $3 \mathrm{R}$, diharapkan masyarakat terutama ibu rumah tangga dapat meminimkan sampah yang dibuang ke lingkungan sehingga lingkungan lebih bersih dan sehat. Selain itu masyarakat mendapatkan nilai tambah dari daur ulang sampah. Sampah tidak dibuang ke sungai atau selokan sehingga aliran sungai dan selokan tetap lancar dan terhindar dari musibah banjir.

\section{KESIMPULAN}

Telah dilakukan kegiatan sosialisasi dan edukasi tentang kontribusi sampah terhadap banjir dan pengelolaan sampah berbasis $3 \mathrm{R}$ dalam rangka mitigasi banjir, serta demonstrasi dan pemutaran video tentang daur ulang sampah pada masyarakat yang tinggal di Kelurahan Sungai Lulut Banjarmasin. Hasil evaluasi dengan pretes dan postes menunjukkan peningkatan bermakna nilai postes dibandingkan dengan nilai pretes, peserta juga tergerak dan memiliki keterampilan dasar dalam mengelola sampah serta cara mendaur ulang sampah dalam rangka mitigasi banjir.

Disarankan agar kegiatan ini dapat berlanjut agar dapat terus mendidik masyarakat untuk dapat mengelola sampah dengan benar sehingga bisa memberi nilai ekonomis bagi masyarakat, serta tidak mencemari lingkungan dan sebagai salah satu upaya mitigasi banjir di daerah tersebut.

\section{UCAPAN TERIMAKASIH}

Ucapan terima kasih kami sampaikan atas partisipasi berbagai pihak yang membantu pelaksaan kegiatan ini, yaitu : Fakultas Kedoteran ULM dan ketua RT serta tokoh masyarakat di wilayah Kelurahan Sungai Lulut Banjarmasin.

\section{REFERENSI}

Badan Lingkungan Hidup Daerah (BLHD) Banjarmasin (2014). Enam Sungai di Banjarmasin tercemar. Versi HTML dari www.inilah.com/mediakalimantan. Diakses tanggal 1 April 2014.

Badan Lingkungan Hidup Daerah (BLHD) Banjarmasin (2012). Enam Sungai di Banjarmasin tercemar. Versi HTML dari www.inilah.com/mediakalimantan. Diakses tanggal 1 April 2013.

CNN Indonesia (2021). Hari Ketiga Banjir di Banjarmasin Kalsel Makin Tinggi.

CNN Indonesia (2021). Banjir Kalsel, Walhi Ingatkan Soal Kerusakan Lingkungan.

Dinkes Kota Banjarmasin (2016). Profil Kesehatan Kota Banjarmasin. Pemerintah Kota Banjarmasin : Banjarmasin.

Haswar AM. 2021. 600 Rumah Terdampak Banjir, Wali Kota Banjarmasin Tetapkan Status Darurat Bencana. Kompas.com

Hariyadi, Chaerani A, Astawati LD, Wijaya RA. (2020). Perencanaan Tempat Pembuangan Sampah dan Pengolahan Sampah Berbasis 3R

\begin{tabular}{l|l} 
Kesehatan & 503
\end{tabular} 
(Reduce, Reuse, Recycle) di Desa Sukadana. Jurnal Warta Desa. 12(1): 66-72.

Heriyani F, Budiarti LY. (2019). Overview Bacteria Isolated from Hand Swab, Feces of Elementary School Students and Water at the Area of Lulut Riverbank in Banjarmasin" has been present in POSTER presentation at $10^{\text {th }}$ International Seminar of Indonesian Society for Microbiology $\left(10^{\text {th }}\right.$ ISISM $) \& 12^{\text {th }}$ Congress of Indonesian Society for Microbiology

Kompas.com dengan Judul "Mitigasi Bencana Banjir", Available https://www.kompas.com/skola/read/2020/01 /04/070000869/mitigasi-bencana-banjir.

Makdori, Y. (2021). Basarnas Sebut 9.600 Jiwa Terdampak Banjir di Banjarmasin. Liputan 6.com.

Notoajmojo, S. (2012). Ilmu Perilaku Kesehatan. JRineka Cipta : Jakarta.

Pusat Litbang SDA. (2004). Status Mutu Air Sungai.

Puskesmas Terminal (2020). Laporan Tahunan Puskesmas Terminal tahun 2019. Puskesmas Terminal : Banjarmasin.

Riswan, Sunoko HR, Agus H. (2011). Pengelolaan Sampah di Rumah Tangga di Kecamatan Daha Selatan. Jurnal Ilmu Lingkungan. 9(1).

Sofarini, D, Rachman, A, Ridwan, I. (2012). Permodelan Uji Logam Berat pada Badan Air, Biota, dan Sedimen di Perairan Muara Das Barito. Jurnal Bumi Lestari. 12 (1) : 7787.

Yulika NC. (2021). BPBD : 100 Ribu Warga Banjarmasin Terdampak Banjir. Liputan 6.com. 